\title{
Development of Maize-T. Aus-T. Aman cropping pattern against Maize-Fallow-T. Aman rice
}

\author{
MUS Khatun*, UK Laily, M Akhter-Ul-Alam, MK Islam, MM Anwar, MAH Talukder
}

On Farm Research Division, Agricultural Research Station, Bangladesh Agricultural Research Institute, Alamnagar, Rangpur, Bangladesh

\begin{abstract}
The field experiment was conducted at MLT site Pirganj, Rangpur and Hatibandha' Lalmonirhat for two consecutive years 2015-16 and 2016-17 to introduce T. Aus in the fallow period and to study the comparative agronomic performance and economic return of two cropping sequences (viz. improved cropping pattern; Maize -T. Aus - T. Aman rice and existing cropping pattern; Maize-Fallow-T. Aman rice) for increasing cropping intensity, productivity and land use efficiency. The experiment was laid out in randomized complete block design with six dispersed replications. Two years mean data showed that the improved management practices for the pattern provided significantly higher yield in improved pattern. Higher rice equivalent yield (REY) of cropping system (mean value $17.34 \mathrm{t} \mathrm{ha}^{-1}$ ) was recorded with the improved pattern over existing pattern at MLT site Pirganj. REY increased $4.60 \mathrm{t} \mathrm{ha}^{-1}$ by inclusion of $\mathrm{T}$. Aus with improved production technologies for the component crops. Similar results were also found in Hatibandha. The gross return of the improved pattern was BDT 346764 ha $^{-1}$ which was more than 33.56\% higher than farmers' pattern of BDT $259640 \mathrm{ha}^{-1}$ at MLT site Pirganj and in Hatibandha gross return of the improved pattern was BDT $342800 \mathrm{ha}^{-1}$ which was more than $27.77 \%$ higher than farmers' pattern of BDT $268300 \mathrm{ha}^{-1}$. The gross margin was higher in improved cropping pattern in both locations than existing pattern due to addition of T. Aus.
\end{abstract}

Key words: Land use efficiency, cropping intensity, economic return

Progressive Agriculturists. All rights reserved

*Corresponding Author: salma_agron@yahoo.com

\section{Introduction}

The $21^{\text {st }}$ century faces multiple challenges like climate change, population growth, food shortage, poverty, hunger, accelerated land cover change and environmental degradation (Neamatollahi et al., 2017). Due to the inadequate food supply, about 1 billion people stay hungry every day in the world and the figure will increase to 2 billion by 2050 . This scenario enforces the increasing momentum in agricultural production with more than 70 percent increase for the developing countries of Asia and Africa in coming decades (Neamatollahi et al., 2017). In this regard,

improved cropping pattern, better management practices are essential to enhance agriculture productivity. Due to the rapid change in population and urbanization, land and water resources are becoming very limited. Subsequently, crop optimization has received extensive attention in recent years and improve cropping pattern have been developed to determine the optimal use of the available resources for maximizing the net benefits subjected to some constraints (Osama et al., 2017). Land and water are 


\section{Cropping pattern development}

the key factors for sustainable agricultural development of a nation.

Bangladesh is one of the most densely populated countries of the world. The population will increase to about 200 million (Planning Commission). On the other hand, the cultivable land is decreasing by $1 \%$ every year. The total land area of Bangladesh is about 14.84 $\mathrm{M}$ ha (million hectares), of which $3.74 \mathrm{M}$ ha ( $25 \%$ of the total) is not available for agriculture due to use for urban areas, industrial buildings, rural homesteads, roads and other infrastructure. The net area of Bangladesh for crop cultivation declined to 7.84 $\mathrm{M}$ ha in 2011 from $8.85 \mathrm{M}$ ha in 1985 (BBS, 2012). Bangladesh also suffers regularly from several natural calamities (Haq et al., 2012; Islam et al., 2017a; Khatun et al., 2016), which may worsen in the future due to climate change (Rokonuzzaman et al., 2018; Hossain et al., 2016). Thus, Bangladesh needs to produce more food on less land to assure future food security for millions of people every year (Islam et al., 2015a\&b). To achieve this, the two techniques that need to be adopted more frequently are an increase in the cropping intensity by producing two or more crops on the same land all-year round, and an increase in the productivity of individual crops, particularly their ability to utilize basic or limiting resources such as water and nutrients (FAOSTAT, 2013; Dobermann et al., 2013; Datta et al., 2015; Ladha et al., 2016; Datta et al., 2017; Islam et al., 2017b).

The major cropping pattern of agriculture in Bangladesh mostly consists of rice based cereal crops (Haque, 1998). Most areas of Bangladesh at present under two crops based cropping pattern, but there prerequisite to increase crop number to meet up the demand. A number of reports on different cropping pattern are available in Bangladesh and abroad (Soni and Kaur, 1984; Malavia et al., 1986; Khan et al., 2005, Ferdous et al., 2011, Anowar et al., 2012, Anowar et al., 2015, Nazrul et al., 2013, Khatun et al., 2016 and Anwar et al., 2017) where an additional crops could be introduced without much changes or replacing the existing ones for considerable increase of the overall productivity as well as profitability of the farmers and pheromone traps used in Bangladesh (Islam, 2012a,b). The areas where Maize-FallowT.aman cropping patterns were practiced there are a great scope of introducing T.aus rice. Keeping these views in mind, the present study was designed to introduce T.aus rice in the fallow period.

\section{Materials and Methods}

The experiment was conducted at the farmers' field condition in khalashpir, Pirgonj, Rangpur (Latitude: $25^{0} 24.249 \mathrm{~N}$, Longitude: $\left.089^{0} 11.946 \quad \mathrm{E}\right)$ and Hatibandha, Lalmonirhat(Latitude: $25^{0} 52.564 \mathrm{~N}$, Longitude: $089^{0} 20.0211$ E) during two consecutive years2015-17. There were two treatments viz., $\mathrm{T}_{1}=$ Existing cropping pattern Maize-Fallow-T. aman rice, $\mathrm{T}_{2}=$ Devloped cropping pattern Maize-T. aus-T. aman rice. The area mostly falls under medium-high land and high land areas of the Agro-Ecological Zone (AEZ) 3 (Tista mender Floodplain). Small un-replicated trials on farmers' fields, known as "dispersed experiments", were established under local farm conditions (Ferdous et al. 2016; Ferdous et al., 2017a,b). The land was divided into two equal plots (each of $660 \mathrm{~m}^{2}$ ) where one plot was maintained either improved pattern, whereas the other plot was maintained existing pattern in khalashpir, Pirgonj, Rangpur and Hatibandha, Lalmonirhat. The details of crop management practices followed for each crop at khalashpir, Pirgonj, Rangpurand Hatibandha, Lalmonirhat location is provided in Tables 1 and 2 respectively.

After physiological maturity, 10 randomly selected plants from each plot were harvested and yield of Maize, T. aus rice and T. aman rice were measured. Yield for each crop was determined plot-wise and converted into yield on an area basis $\left(\mathrm{kg} \mathrm{ha}^{-1}\right)$. Benefitcost analysis was conducted to estimate the economic feasibility of Maize, T. aus rice and T. aman rice crop. The production costs of these crops included the cost of field preparation, seed, planting, irrigation, fertilizers, 
crop protection measures and harvesting. The gross income was estimated using the prevailing average market prices for the yield of these crops in Bangladesh. Net income was calculated by subtracting total expenditure from the gross income which was computed by dividing the gross income with total expenditure (Mahamood et al., 2016, Ferdous et al. 2017c,d, 2018).

Table 1. Crop management practices in improved cropping pattern and existing cropping pattern at MLT site of Pirganj in Rangpur.

\begin{tabular}{|c|c|c|c|c|c|c|}
\hline Observation & \multicolumn{3}{|c|}{ Existing cropping pattern } & \multicolumn{3}{|c|}{ Improved cropping pattern } \\
\hline Crop & Maize & Fallow & T. Aman & Maize & T. Aus & T. Aman \\
\hline Variety & $\begin{array}{c}\text { Kaveri } \\
50\end{array}$ & - & BR 11 & BHM-9 & $\begin{array}{c}\text { BRRI dhan } \\
48\end{array}$ & $\begin{array}{c}\text { BRRI dhan } \\
57\end{array}$ \\
\hline Spacing & $\begin{array}{c}60 \mathrm{~cm} \\
\mathrm{x} 20 \mathrm{~cm}\end{array}$ & - & $\begin{array}{c}25 \mathrm{~cm} \mathrm{x} 15 \\
\mathrm{~cm}\end{array}$ & $60 \mathrm{~cm} \times 20 \mathrm{~cm}$ & $\begin{array}{c}25 \mathrm{~cm} \mathrm{x} 15 \\
\mathrm{~cm}\end{array}$ & $25 \mathrm{~cm} \mathrm{x} 15 \mathrm{~cm}$ \\
\hline Unit plot size & \multicolumn{3}{|c|}{$1320 \mathrm{~m}^{2}$} & \multicolumn{3}{|c|}{$1320 \mathrm{~m}^{2}$} \\
\hline $\begin{array}{l}\text { Fertilizer dose } \\
(\mathrm{N}-\mathrm{P}-\mathrm{K}-\mathrm{S}-\mathrm{Zn}-\mathrm{B} \\
\left.\mathrm{Kg} \mathrm{ha}^{-1}\right)\end{array}$ & $\begin{array}{l}184-32- \\
75-21- \\
3-1.20\end{array}$ & - & $\begin{array}{c}134-30-40- \\
13-2-0.70\end{array}$ & $\begin{array}{c}235-42-80-27.2- \\
3.58-1.2\end{array}$ & $\begin{array}{c}\text { 76-12-33-9- } \\
1.2-0\end{array}$ & $\begin{array}{c}114-35-80- \\
22-0-0\end{array}$ \\
\hline $\begin{array}{l}\text { Date of sowing/ } \\
\text { transplanting }\end{array}$ & $\begin{array}{l}25 \text { Nov- } \\
10 \mathrm{Dec}\end{array}$ & - & $\begin{array}{l}\text { 25July-15 } \\
\text { Aug }\end{array}$ & $20-25 \mathrm{Nov}$ & 07-12 May & 15-20 Aug \\
\hline Harvesting date & $\begin{array}{l}01-15 \\
\text { May }\end{array}$ & & $10-20 \mathrm{Nov}$ & $\begin{array}{l}30 \text { April-05 } \\
\text { May }\end{array}$ & 08-15 Aug & $10-15$ Nov \\
\hline
\end{tabular}

Table 2. Crop management practices in improved cropping pattern and existing cropping pattern at MLTsite of Hatibandha in Lalmonirhat

\begin{tabular}{|c|c|c|c|c|c|c|}
\hline Observation & \multicolumn{3}{|c|}{ Existing cropping pattern } & \multicolumn{3}{|c|}{ Improved cropping pattern } \\
\hline Crop & Maize & Fallow & T. Aman & Maize & T. Aus & T. Aman \\
\hline Variety & Kaveri 50 & - & sawrna & $3 \mathrm{~S} 981$ & $\begin{array}{l}\text { BRRI dhan } \\
\quad 48\end{array}$ & BRRI dhan 56 \\
\hline Spacing & $\begin{array}{c}60 \mathrm{~cm} \mathrm{x} \\
20 \mathrm{~cm}\end{array}$ & - & $\begin{array}{c}25 \mathrm{~cm} \mathrm{x} 15 \\
\mathrm{~cm}\end{array}$ & $60 \mathrm{~cm} \times 20 \mathrm{~cm}$ & $\begin{array}{c}20 \mathrm{~cm} \mathrm{x} 15 \\
\mathrm{~cm}\end{array}$ & $25 \mathrm{~cm} \mathrm{x} 15 \mathrm{~cm}$ \\
\hline Unit plot size & \multicolumn{3}{|c|}{$1320 \mathrm{~m}^{2}$} & \multicolumn{3}{|c|}{$1320 \mathrm{~m}^{2}$} \\
\hline $\begin{array}{l}\text { Fertilizer dose } \\
(\mathrm{N}-\mathrm{P}-\mathrm{K}-\mathrm{S}-\mathrm{Zn}-\mathrm{B} \\
\left.\mathrm{Kg} \mathrm{ha}^{-1}\right)\end{array}$ & $\begin{array}{c}175-30- \\
70-20-2-1\end{array}$ & - & $\begin{array}{c}130-20-30- \\
11-2-0.5\end{array}$ & $\begin{array}{c}235-42-80- \\
27.2-3.58-1.2\end{array}$ & $\begin{array}{c}76-12-33-9- \\
1.2-0\end{array}$ & $\begin{array}{c}114-35-80-22- \\
0-0\end{array}$ \\
\hline $\begin{array}{l}\text { Date of sowing/ } \\
\text { transplanting }\end{array}$ & $\begin{array}{c}\text { 30Nov-10 } \\
\text { Dec }\end{array}$ & - & $\begin{array}{l}\text { 20July-10 } \\
\text { Aug }\end{array}$ & 18-22 Nov & 05-10 May & 14-20 Aug \\
\hline Harvesting date & $\begin{array}{l}05-15 \\
\text { May }\end{array}$ & & 05-15 Nov & $\begin{array}{l}28 \text { April-02 } \\
\text { May }\end{array}$ & 06-12 Aug & 10-16 Nov \\
\hline
\end{tabular}


Productivity of different cropping systems was compared in terms of rice equivalent yield (REY). Land use efficiency and rice equivalent yield of cropping patterns were calculated. Land use efficiency was worked-out by taking total duration of crops in an individual cropping pattern divided by 365 days. It was calculated by the following formula:

Land Use Efficiency $(\%)=\frac{d_{1}+d_{2}+d_{3}+d_{4}}{365} \times 100$

Where $d_{1}, d_{2}$ and $d_{3}$ the duration of $1^{\text {st }}, 2^{\text {nd }}$ and $3^{\text {rd }}$ crop of the pattern

Production efficiency value in terms of kg ha-1day1 was calculated by total main production a cropping pattern divided by total duration of crops in that pattern (Lal et al., 2017; Tomar and Tiwari, 1990).

Rice Equivalent Yield (REY): For comparison between crop sequences, the yield of all crops was converted into rice equivalent on the basis of prevailing market prices of individual crop (Lal et al., 2017). Rice equivalent yield (REY) was computed as yield of individual crop multiplied by market price of that crop divided by market price of rice.

REY $\left(\mathrm{t} \mathrm{ha}^{-1}\right)=\frac{\text { ield of individual crop xmarket price of that crop }}{\text { Market price of rice }}$

\section{Results and Discussion}

Yield of the Cropping Patterns: Results of the study have been presented in Table $3 \& 5$. It was revealed that the entire component crops of Maize-T. aus-T. Aman rice cropping pattern under improved practices (IP) gave higher yield as well as by-product yield in two consecutive years at both the locations. The yield of improved pattern was higher due to inclusion of t.aus ricewith improved production technologies for the component crops. Similar results were also obtained by Anwar et al., 2017, Khatun et al., (2016), Kamrozzaman et al., (2015) and Nazrul et al. (2013). BRRI dhan48 is a short duration high yielding T.aus rice variety which can easily be grown during the fallow period (Mondal et. al., 2015). Inclusion of mustard with improved variety in Maize-T.aus-T. Aman rice cropping pattern practice increased the total yield over the farmers existing cropping pattern practice. Grain yields of $T$. aman rice in case of improved cropping pattern were 3.90 and $3.83 \mathrm{t} \mathrm{ha}^{-1}$ at MLT site Pirganj and 3.74 and $3.75 \mathrm{tha}^{-1}$ at MLT site Hatibandha in two consecutive years respectively. Grain yield of maize were 9.96 and $9.87 \mathrm{t} \mathrm{ha}^{-1}$ at MLT site Pirganj and 9.80 and $12.07 \mathrm{tha}^{-1}$ at MLT site Hatibandha in two consecutive years respectively. Grain yield of T. aus rice were 4.02 and $4.15 \mathrm{t} \mathrm{ha}^{-1}$ at MLT site Pirganj and 3.58 and $3.91 \mathrm{t} \mathrm{ha}^{-1}$ at MLT site Hatibandha in two consecutive years respectively.

Rice equivalent yield: Total productivity of a cropping system was evaluated in terms of rice equivalent yield (REY) and it was calculated from yield of component crops. Higher rice equivalent yield (REY) of cropping system (mean value $17.34 \mathrm{tha}^{-1}$ ) was recorded with the improved pattern over existing pattern at MLT site Pirganj (Table 4). REY increased $4.36 \mathrm{t} \mathrm{ha}^{-1}$ by inclusion of T.aus rice with improved production technologies for the component crops. Similar results were also found in Domar (Table 6). It is noted that inclusion of additional crop during the fallow period produced higher REY than farmer's practice. Similar results were also obtained by different research group (Khatun et al., 2016; Kamrozzaman et al., 2015; Ferdous et al. 2011, Anowar et al. 2012, Nazrul et al., 2013).

Crop Duration: On an average, cropping pattern comprises existing cropping pattern and improved cropping pattern took 257 and 326 days excluding seedling age of T.aus and T. Aman rice to complete the cycle. It is observed that T.aus rice could be easily fitted in the cropping pattern with turn-around time of 39 days in a year.

Land use efficiency: Land use efficiency is the effective use of land in a cropping year, which mostly depends on crop duration. Results of the study have been presented in Table $4 \& 6$. 
Table 3. Productivity of farmers' and improved cropping pattern at MLT site of Pirganj in Rangpur

\begin{tabular}{|c|c|c|c|c|c|c|}
\hline Year & $\begin{array}{c}\text { Cropping } \\
\text { pattern }\end{array}$ & Crop & Variety & $\begin{array}{c}\text { Field } \\
\text { duration }\end{array}$ & $\begin{array}{c}\text { Grain or seed } \\
\text { yield }\left(\mathrm{t} \mathrm{ha} \mathbf{h}^{-1}\right)\end{array}$ & $\begin{array}{c}\text { Straw or Stover } \\
\text { yield }\left(\mathrm{t} \mathrm{ha}^{-1}\right)\end{array}$ \\
\hline \multirow[t]{6}{*}{$2015-16$} & \multirow{3}{*}{$\begin{array}{c}\text { Existing } \\
\text { cropping } \\
\text { pattern }\end{array}$} & Maize & Kaveri 50 & 159 & 10.14 & - \\
\hline & & Fallow & - & - & - & - \\
\hline & & T.aman & BR 11 & 105 & 3.97 & 4.93 \\
\hline & \multirow{3}{*}{$\begin{array}{l}\text { Improved } \\
\text { cropping } \\
\text { pattern }\end{array}$} & Maize & BHM-9 & 153 & 9.96 & - \\
\hline & & T. Aus & BRRI dhan 48 & 87 & 4.02 & 4.42 \\
\hline & & T.aman & BRRI dhan 57 & 85 & 3.90 & 4.80 \\
\hline \multirow[t]{6}{*}{$2016-17$} & \multirow{3}{*}{$\begin{array}{c}\text { Existing } \\
\text { cropping } \\
\text { pattern }\end{array}$} & Maize & Kaveri 50 & 158 & 10.67 & - \\
\hline & & Fallow & - & - & - & - \\
\hline & & T.aman & BR 11 & 105 & 3.85 & 4.81 \\
\hline & \multirow{3}{*}{$\begin{array}{l}\text { Improved } \\
\text { cropping } \\
\text { pattern }\end{array}$} & Maize & BHM-9 & 150 & 9.87 & - \\
\hline & & T. Aus & BRRI dhan48 & 90 & 4.15 & 5.19 \\
\hline & & T.aman & BRRI dhan 57 & 88 & 3.83 & 4.78 \\
\hline
\end{tabular}

Table 4. Rice-equivalent yield and land use efficiency of farmers' and improved cropping pattern at MLT site of Pirganj in Rangpu

\begin{tabular}{|c|c|c|c|}
\hline Year & Cropping pattern & $\operatorname{REY}\left(\mathrm{t} \mathrm{ha}^{-1}\right)$ & Land use efficiency (\%) \\
\hline \multirow[t]{2}{*}{$2015-16$} & Existing cropping pattern & 12.83 & 72.32 \\
\hline & Improved cropping pattern & 17.29 & 89.04 \\
\hline \multirow[t]{2}{*}{$2016-17$} & Existing cropping pattern & 13.12 & 72.05 \\
\hline & Improved cropping pattern & 17.39 & 89.86 \\
\hline \multirow[t]{2}{*}{ Mean } & Existing cropping pattern & 12.98 & 72.19 \\
\hline & Improved cropping pattern & 17.34 & 89.45 \\
\hline
\end{tabular}

Table 5. Productivity of farmers' and improved cropping pattern at MLT site of Hatibandha in Lalmonirhat

\begin{tabular}{|c|c|c|c|c|c|c|}
\hline Year & $\begin{array}{c}\text { Cropping } \\
\text { pattern }\end{array}$ & Crop & Variety & $\begin{array}{c}\text { Field } \\
\text { duration }\end{array}$ & $\begin{array}{c}\text { Grain or seed } \\
\text { yield }\left(\mathrm{t} \mathrm{ha}^{-1}\right)\end{array}$ & $\begin{array}{c}\text { Straw or stover } \\
\text { yield }\left(\mathrm{t} \mathrm{ha}^{-1}\right)\end{array}$ \\
\hline \multirow[t]{6}{*}{ 2015-16 } & \multirow{3}{*}{$\begin{array}{c}\text { Existing } \\
\text { cropping } \\
\text { pattern }\end{array}$} & Maize & Kaveri 50 & 154 & 10.68 & - \\
\hline & & Fallow & - & - & - & - \\
\hline & & T.aman & Sawrna & 95 & 3.72 & 4.65 \\
\hline & \multirow{3}{*}{$\begin{array}{c}\text { Improved } \\
\text { cropping } \\
\text { pattern }\end{array}$} & Maize & $3 \mathrm{~S} 981$ & 153 & 9.8 & - \\
\hline & & T. Aus & BRRI dhan48 & 82 & 3.58 & 4.48 \\
\hline & & T.aman & BRRI dhan56 & 91 & 3.74 & 4.69 \\
\hline \multirow[t]{6}{*}{ 2016-17 } & \multirow{3}{*}{$\begin{array}{c}\text { Existing } \\
\text { cropping } \\
\text { pattern }\end{array}$} & Maize & Kaveri 50 & 160 & 11.67 & - \\
\hline & & Fallow & - & - & - & - \\
\hline & & T.aman & Sawrna & 95 & 3.89 & 4.86 \\
\hline & \multirow{3}{*}{$\begin{array}{c}\text { Improved } \\
\text { cropping } \\
\text { pattern }\end{array}$} & Maize & 3S 981 & 155 & 12.07 & - \\
\hline & & T. Aus & BRRI dhan 48 & 86 & 3.91 & 4.89 \\
\hline & & T.aman & BINAdhan 7 & 87 & 3.75 & 4.68 \\
\hline
\end{tabular}


Table 6. Rice-equivalent yield and land use efficiency of farmers' and improved cropping pattern at MLT site of Hatibandha inLalmonirhat.

\begin{tabular}{|l|c|c|c|}
\hline Year & Cropping pattern & REY $\left(\mathbf{t ~ h a}^{-\mathbf{1}}\right)$ & Land use efficiency (\%) \\
\hline \multirow{3}{*}{$2015-16$} & Existing cropping pattern & 12.91 & 68.22 \\
\cline { 2 - 4 } & Improved cropping pattern & 16.04 & 89.32 \\
\hline \multirow{2}{*}{$2016-17$} & Existing cropping pattern & 13.92 & 69.86 \\
\cline { 2 - 4 } & Improved cropping pattern & 18.25 & 89.85 \\
\hline \multirow{2}{*}{ Mean } & Existing cropping pattern & 13.42 & 69.04 \\
\cline { 2 - 4 } & Improved cropping pattern & 17.15 & 68.22 \\
\hline
\end{tabular}

Mean land use efficiency indicated that improved cropping pattern used the land for $89.52 \%$ period of the year, whereas ECP used the land for $70.62 \%$ period of the year. The improved cropping pattern leads to higher land use efficiency due to longer period field occupied by the crops (326 days), whereas the farmers practice occupied the field for 257 days of the year. Similar results were also obtained by Khatun et al. (2016) and Alam et al. (2017).
Economic analysis: Economic analysis done based on prevailing market price during the crop Season. Improved cropping pattern showed its superiority over farmers' pattern during two consecutive years at both the locations. Results of the study have been presented in Table $7 \& 8$.

Table 7. Cost benefit analysis of farmers' and improved cropping pattern at MLT site of Pirganj in Rangpur

\begin{tabular}{|c|c|c|c|c|c|}
\hline Year & Cropping pattern & $\begin{array}{c}\text { Gross return } \\
\left(\text { Tk. } \mathrm{ha}^{-1}\right)\end{array}$ & $\begin{array}{l}\text { Total variable } \\
\text { cost }\left(\mathrm{Tk} \mathrm{ha}^{-1}\right)\end{array}$ & $\begin{array}{l}\text { Whole pattern } \\
\text { GM }\left(\mathrm{Tk}^{-h^{-1}}\right)\end{array}$ & $\begin{array}{l}\text { Benefit over } \\
\text { existing pattern }\end{array}$ \\
\hline \multirow[t]{2}{*}{ 2015-16 } & Existing cropping pattern & 256710 & 110990 & 145720 & \multirow[t]{2}{*}{41900} \\
\hline & Improved cropping pattern & 345780 & 158160 & 187620 & \\
\hline \multirow[t]{2}{*}{ 2016-17 } & Existing cropping pattern & 262570 & 112110 & 150460 & \multirow[t]{2}{*}{37537} \\
\hline & Improved cropping pattern & 347747 & 159750 & 187997 & \\
\hline \multirow[t]{2}{*}{ Mean } & Existing cropping pattern & 259640 & 111550 & 148090 & \multirow[t]{2}{*}{39718} \\
\hline & Improved cropping pattern & 346764 & 158955 & 187809 & \\
\hline
\end{tabular}

On an average, gross return of the improved pattern was BDT $346764 \mathrm{ha}^{-1}$ which was more than $33.56 \%$ higher than farmers' pattern of BDT $259640 \mathrm{ha}^{-1}$ at MLT site Pirganj (Table 7) and in Hatibandha gross return of the improved pattern was BDT 342800 ha $^{-1}$ which was more than $27.77 \%$ higher than farmers' pattern of BDT $268300 \mathrm{ha}^{-1}$ (Table 8). The production cost of the improved pattern (BDT $158950 \mathrm{ha}^{-1}$ ) was higher than farmers' pattern (BDT $111550 \mathrm{ha}^{-1}$ ) due to labor intensive, cost of fertilizer and other inputs (Table 7). Similar results were also found in Hatibandha. The net return was substantially higher in 
the improved pattern (BDT $187809 \mathrm{ha}^{-1}$ ) than farmers' pattern of BDT $148090 \mathrm{ha}^{-1}$ at MLT site Pirganj and in Hatibandha it was also substantially higher in the improved pattern (BDT $206591 \mathrm{ha}^{-1}$ ) than farmers' pattern of BDT $167008 \mathrm{ha}^{-1}$.

Table 8. Cost benefit analysis of farmers' and improved cropping pattern at MLT site of Hatibanda in Lalmonirhat

\begin{tabular}{|l|c|c|c|c|c|}
\hline Year & Cropping pattern & $\begin{array}{c}\text { Gross Return } \\
\left(\mathrm{Tk}^{-\mathrm{ha}^{-1}}\right)\end{array}$ & $\begin{array}{c}\text { Total Variable } \\
\text { Cost }\left(\mathrm{Tk} . \mathrm{ha}^{-1}\right)\end{array}$ & $\begin{array}{c}\text { Whole } \\
\text { pattern GM } \\
\left(\mathrm{Tk}^{-1} \mathrm{~h}^{-1}\right)\end{array}$ & $\begin{array}{c}\text { Benefit over } \\
\text { existing } \\
\text { pattern }\end{array}$ \\
\hline \multirow{2}{*}{$2015-16$} & Existing cropping pattern & 258200 & 98986 & 159214 & 34958 \\
\cline { 2 - 5 } & Improved cropping pattern & 320700 & 126528 & 194172 & \\
\hline \multirow{2}{*}{$2016-17$} & Existing cropping pattern & 278400 & 103599 & 174801 & \multirow{2}{*}{44209} \\
\cline { 2 - 5 } & Improved cropping pattern & 364900 & 145890 & 219010 & \\
\hline Mean & Existing cropping pattern & 268300 & 101293 & 167008 & \multirow{2}{*}{39583} \\
\cline { 2 - 5 } & Improved cropping pattern & 342800 & 136209 & 206591 & \\
\hline
\end{tabular}

The higher net return of the improved pattern was achieved mainly higher yield advantages of the component crops. Inclusion of new crop (T. Aus rice) as well as improvement of management practices in the improved cropping pattern increased the economic return. Similar results were also obtained by Khatun et al. (2016).

\section{Conclusion}

From the above results showed that improved cropping pattern was more profitable compared to existing pattern. Considering higher rice-equivalent yield, net monetary return and more sustainability of the improved cropping pattern (Maize-T. Aus-T. Aman rice) with additional crop and improved technologies could be suggested for medium high land of the Teesta Meander Floodplain Agro-ecological Zone (AEZ- 3) of Bangladesh.

\section{References}

Alam MAU, Ferdous Z, Islam K, Khatun MUS, Akter MB, Laily UK, Anwar M, Sarker KK (2017). Sustainable Water Management for Potato Production in Drought Prone Areas in
Bangladesh. Annual Research \& Review in Biology.21(3): $\quad 1-9, \quad 2017 . \quad$ DOI: 10.9734/ARRB/2017/37622.

Anowar M, Parveen A, Ferdous Z, Kafi AH, Kabir ME (2015). Baseline survey for farmer livelihood improvement at farming system research and development, Lahirirhat, Rangpur. Int. J. Bus. Manag. Soc. Res. 2:92-104.

Anowar MM, MZ Ferdous and Mozidul I (2012). Determination of nutrient management for Potato-Mungbean-T.aman rice cropping pattern. Bangladesh J. Prog. Sci. \& Tech. 10(2): 173-176.

Anwar M, Ferdous Z, Sarker MA, Hasan AK, Akhter MB, Zaman MAU, Haque Z, Ullah H (2017). Employment Generation, Increasing Productivity and Improving Food Security through Farming Systems Technologies in the Monga Regions of Bangladesh.Annu. Res. Rev. Biol.16(6):1-15.

BBS (Bangladesh Bureau of Statistics) (2011). Yearbook of agricultural statistics of Bangladesh. Dhaka: Bangladesh Bureau of Statistics, Statistics Division, Ministry of Planning, Government of the People's Republic of Bangladesh. 
BBS (Bangladesh Bureau of Statistics) (2012). Yearbook of Agricultural Statistics of Bangladesh. Bangladesh Bureau of Statistics, Statistics Division, Ministry of Planning, Government of People's Republic of Bangladesh, Dhaka.

Datta A, Shrestha S, Ferdous Z, Win CC (2015). Strategies for Enhancing Phosphorus Efficiency in Crop Production Systems. In: A Rakshit, HB Singh, A Sen (Eds.), Nutrient Use Efficiency: from Basics to Advances. pp. 59-71. Springer, ISBN 978-81-322-2169-2

Datta A, Ullah H, Ferdous Z (2017). Water Management in Rice. In: BS Chauhan, K Jabran, G Mahajan (Eds.), Rice Production Worldwide. pp. 255-277.

Dobermann A, Nelson R, Beever, Bergvinson D, Crowley E, Denning G, Giller K, Arros J, Hughes M, Jahn J, Lynam W, Masters R, Naylor G, Neath I, Onyido T, Remington I, Wright F, Zhang F (2013). Solutions for Sustainable Agriculture and Food Systems, Technical Report for the PostDevelopment Agenda. Sustainable Development Solutions Network, New York, pp. 1-99.

FAOSTAT (Food and Agriculture Organization Corporate Statistical Database) (2013). FAO, Rome, Italy.

Ferdous MZ, Anwar MM, Haque Z, MahamudNU, Hossain MM (2014). Comparative performance of two magnesium sources on yield and yield attributes of potato. Bangladesh J. Environ. Sci.27: 98-10.

Ferdous Z, Anwar M, Haque Z, Islam MK, Khatun MUS, Alam MA (2017e). Sustainable food security through cropping system analysis using different farming technologies at northern region of Bangladesh.Progressive Agriculture 28 (3): 204-215.

Ferdous Z, Anwar M, Rahman MA, Yasmine F, Nain J. (2011). Fertilizer management for maizemungbean-T. aman based cropping pattern.
Journal of Agroforestry and Environment. 5, $129-132$.

Ferdous Z, Anwar M, Uddin N, Ullah H, Hossain A (2017d). Yield performance of okra (Abelmoschus esculentus) through integrated nutrient management. Int. J. Biosci.10 (1): 294301.

Ferdous Z, Datta A, Anwar M. (2017c). Synthetic pheromone lure and apical clipping affects productivity and profitability of eggplant and cucumber, International Journal of Vegetable Science, DOI: 10.1080/19315260.2017.1407858.

Ferdous Z, Datta A, Anal AK, Anwar M, Khan MR (2016). Development of home garden model for year round production and consumption for improving resource-poor household food security in Bangladesh. NJAS - Wageningen Journal of Life Science. 78, 103-110.

Ferdous Z, Datta A, Anwar M (2017a). Effects of plastic mulch and indigenous microorganism on yield and yield attributes of cauliflower and tomato in inland and coastal regions of Bangladesh. J. Crop Improv.31: 261-279. doi:10.1080/15427528.2017.1293578.

Ferdous Z, Hossain A, Mahmud NU, Ali R, Ahmed NU (2017b). Effect of poultry manure and lime in combination with chemical fertilizer on groundnut production in char areas under tista mender flood plain agro ecological zone in Bangladesh.Int. J. Sustain. Crop Prod. 12(1):1014.

Ferdous Z, Ullah H, Datta A, Anwar M, Ali M (2018). Yield and Profitability of Tomato as Influenced by Integrated Application of Synthetic Fertilizer and Biogas Slurry. International Journal of Vegetable Science. DOI:10.1080/19315260.2018. 1434585.

Haq MZ, M Robbani, Ali M, Hasan MM, Uddin MJ, Begum M, Teixeira da Silva JA, Pan XY, Karim MR (2012). Damage and management of Cyclone Sidr-affected homestead tree plantations: a case 
study from Patuakhali, Bangladesh. Nat. Hazards. 64 (2): 1305-1322.

Haque MS (1998). Integrated nutrient management with inorganic and biofertilizers in legume based cropping patterns. Proc. of the nationalworkshop on integrated nutrient management for crop production and soil fertility. 24-25 March, 1998. BARC, Gazipur. pp.99-109.

Hossain MS, Hossain A, Sarkar MAR, Jahiruddin M, Teixeira da Silva JA, Israil HM (2016). Productivity and soil fertility of the rice-wheat system in the high Ganges River floodplain of Bangladesh is influenced by the inclusion of legumes and manure. Agric. Ecosyst. Environ. 218: 40-52.

Islam MA, Parvin S, Faruk MA (2017a). Impacts of riverbank erosion hazards in the Brahmaputra floodplain areas of Mymensingh in Bangladesh. Progressive Agriculture, 28(2): 73-83.

Islam MA, Akhter D, Faruk MA (2017b). Q-GIS Mapping To Explore the Status of Quality of Drinking Water in Bangladesh. IOSR Journal of Environmental Science, Toxicology and Food Technology (IOSR -JESTFT), 11(8): 17-27.

Islam MA, Haq ME, Hossain MK, Hossen MS (2015a). Investigation of formalin and ethepon in some fruits of three local markets of Mymensingh district using gas chromatograph. J. Bangladesh Agril. Univ., 13(1): 7-12.

Islam MA, Islam MZ, Hossain MK (2015b). Residual analysis of selected pesticides in cucumber and spinach collected from local markets of Mymensingh sadar. Progressive Agriculture, 26(1): 38-44.

Islam MA (2012a). Pheromone use for insect control: present status and prospect in Bangladesh. Int. J. Agril. Res. Innov. \& Tech.,. 2 (1): 47-55.

Islam MA (2012b). Knowledge and Practice of Pheromone Technologies: A case Study of a Representative District in Bangladesh. Academic Research International 2(2):55-61.
Kamrozzaman MM, Khan MAH, Ahmed S, Quddus AFMR (2015). On-farm evaluation of production potential and economics of Wheat-Jute-T.aman rice-based cropping system. J. Bangladesh Agril. Univ. 13(1): 93-100.

Khan MAH,. Quayyum MA, Nazrul MI, Sultana N, Mollah MRA (2005). On-farm evaluation of production potential and economics of MustardRice based improved cropping system. J. Socio. Res. Dev. 2(1): 37-42.

Khatun MUS, Alam MAU, Hossain MA, Islam MK, Anwar MM, Haque ME (2016). Evaluation of production potential and economics of RadishPotato/Maize-T. Aman cropping pattern in Rangpur region. Journal of Science, Technology and Environment Informatic, 4(02):293-300.

Khatun M, MA Islam, MA Haque (2016). Studies of thunderstorms and lightning on human health, agriculture and fisheries in Mymensingh and Jamalpur district of Bangladesh. Progressive Agriculture, 27: 57-63.

Ladha JK, Rao AN, Raman AK, Padre AT, Dobermann A, Gathala M, Kumar V, Saharawat Y, Sharma S, Piepho HP, Alam MM, Liak R, Rajendran R, Reddy CK, Parsad R, Sharma PC, Singh SS, Saha A, Noor S (2016). Agronomic improvements can make future cereal systems in South Asia far moreproductive and result in a lower environmental footprint. Glob Change Biol. 22: 1054-1074.

Lal B, Gautam P, Panda BB, Raja R, Singh T, Tripathi $R$ (2017). Crop and varietal diversification of rainfed rice based cropping systems for higher productivity and profitability in Eastern India. PLoS ONE. 12(4): e0175709.

Mahamood NU, Ferdous Z, Anwar M, Ali R, Sultana $M$ (2016). Yield maximization of maize through nutrient management. Progressive Agriculture. 27 (4): 428-434.

Malavia DD, Singh MP, Vyas MM, Patel JC, Kalaria KK (1986). Production potential and economic 


\section{Cropping pattern development}

feasibility of different crop sequences. Indian $\mathrm{J}$. Argon. 31(1): 75-78.

MoEF (2012). Rio+20: National Report on sustainable development. Dhaka: Ministry of Environment and Forest, Government of the Peoples' Republic of Bangladesh.

Mondal RI, Begum F, Aziz A, Sharif SH (2015). Crop sequences for increasing cropping intensity and productivity. SAARC J. Agri., 13(1):135-147.

Nazrul MI, Shaheb MR, Khan MAH, Khan ASMMR (2013). On-Farm evaluation of production potential and economic returns of potato-rice based improved cropping system. Bangladesh Agron. J. 16 (2):41-50.

Neamatollahi E, Vafabakhshi J, Jahansuz MR, Sharifzadeh F (2017). Agricultural optimal Cropping pattern determination based on fuzzy system. Fuzzy information and Engineering. 9, 479-491.
Osama S, Elkholy M, Kansoh RM (2017). Optimization of the cropping pattern in Egypt. Alexandria Engineering Journal. 56, 557-566.

Rahman MM, Yasmine F, Rahman MA, Ferdous Z, Kar PS (2011). Performance of poultry bio-slurry as a source of organic manure on potato production. J. Agrofor. Environ. 5:81-84.

Rokonuzzaman M, Rahman MA, Yeasmin M, Islam MA (2018). Relationship between precipitation and rice production in Rangpur district. Progressive agriculture, 29(1): 10-21.

Sarker MAI, Ferdous Z, Anwar M, Mahamud NU, Ali M (2010). Performance of poultry bio-slurry as a source of organic manure on wheat production. Bangladesh J. Environ. Sci. 19:36-38.

Soni PN, Kaur R (1984). Studies on production potential of different cropping systems. Indian J. Agron. 29 (3): 367-78. 